2012, Vol. 1, Issue 3-4

\title{
FINALITY OF JUDGMENT \\ IN THE CONTEXT OF THE REVISION PROVIDED FOR BY THE RULES OF THE EUROPEAN COURT OF HUMAN RIGHTS
}

\author{
Bożena Gronowska*
}

The original version of the European Convention of Human Rights of 1950 ("ECHR") introduced a strict rule concerning the finality of judgments of the European Court of Human Rights ("ECtHR"). In its original version, Article 52 ECHR stated that "the judgment of the Court shall be final" and, consequently, the Authors of the Convention provided no exceptions to this rule in the treaty. It should be noted that this attitude was the logical consequence of an assumption that the European level represented the final stage of judicial supervision, following the exhaustion of domestic legal review. Accordingly, in relatively early Strasbourg jurisprudence it was underlined that "the sole object of Article 52 was to make the Court's judgment not subject to any appeal to another authority"1.

Thus, it was the highest possible level of adjudication on cases concerning the violation of a particular right or freedom of individual persons falling within the scope of the ECHR system. Such a solution does not deserve strong criticism, since it enhances the prestige of the ECtHR.

* Nicolas Copernicus University in Toruń.

1 The case of Ringeisen v. Austria (Article 50), Application No. 2614/65, judgment of 22.6.1972, at para 17 . 
However, it cannot be forgotten that for the same interest it is extremely important that judgments delivered by the ECtHR (or similar organs) are totally proper and have a solid justification in the established facts and law. It is a general legal truth that a fair judicial system operates better when there exists a possibility to verify the content of the judgments at stake ${ }^{2}$.

Actually, despite the strict formulation of Article 52 ECHR, the Authors of the judicial review system of this treaty provided for an interesting solution which was connected with two different institutions included in the Rules of the Court ${ }^{3}$, i.e., (1) request for interpretation of the judgment; and (2) request for revision of the judgment.

It seems that, in a given context, both of these institutions may "affect" the meaning of the final ECtHR judgments. Since a request for revision can result in far-reaching consequences as regards the finality of judgments, it will be the main focus of this article. Indeed, in ECtHR Rule 58 of $1959^{4}$ entitled "Request for revision of a judgment" one could and still can (pursuant to the current Rule 80) read that:

"A party or the Commission may, in the event of the discovery of a fact which might by its nature have a decisive influence and which, when a judgment was delivered, was unknown both to the Court and to that Party or Commission, request the Court, within a period of six months after that Party or the Commission, as the case may be, acquired knowledge of such fact, to revise that judgment."

Even a brief glance at the quoted rule can lead to the conclusion that the possibility for revision of a judgment in the ECHR system was

2 It should be added that, as of 1998, i.e., from the moment of the entry into force in 1994 of additional Protocol No. 11 to the ECHR, the final nature of judgments received a conditional character because of the creation of the 17-judge Grand Chamber which was empowered, inter alia, to reconsider judgments decided by a 7-judge Chamber; for more details see: B. Gronowska, Wielka Izba i jej rola $w$ kształtowaniu orzecznictwa Europejskiego Trybunału Praw Człowieka [The Grand Chamber and its role in the establishment of the case-law of the European Court of Human Rights], 'Studia Prawnicze' 2012, No. 3-4 (forthcoming).

3 L.E. Pettitti, E. Decaux, P.H. Imbert, P.H. Teitgen, La Convention européenne des droits de l'homme: commentaire article par article, Paris 1995, at p. 845.

4 Such a solution is contained in every version of the Rules of the Court, i.e., beginning in the Rules of 18.9.1959 and continuing to the current Rules of 1.4.2011. 
intended to be exceptional. Thus, it should be noted that this possibility was restricted not only by time limits but even more strictly by the flexible criterion of a "decisive influence" that such a new fact might have upon the conclusion of the original judgment ${ }^{5}$. Likewise, the rules make it clear that not every request produces automatic effect and is firstly subjected to consideration by the Chamber (Screening Panel) constituted in accordance with the Convention principles, which rules on whether the request is admissible or not. Only in the event of an affirmative opinion does the Chamber refer the request to the Chamber which handed down the original judgment or alternatively, in the event that this proves problematic, to the Chamber which ruled on the merits of the case itself.

It should be noted that there is no need for the so-called Screening Panel to adopt a unanimous decision as regards the admissibility of the revision request, i.e., the particular members may disagree as to the interpretation of the content of the rule at stake. In the Panel's opinion "its role does not extend to determining whether unanimity or majority was required for the rejection of a request submitted by a private

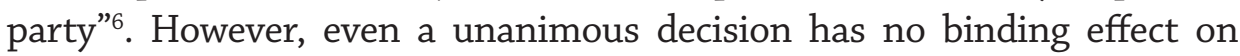
the Chamber dealing with the merits of the revision. Thus, "a decision on the admissibility of the request in no way prejudges the merits of the request"'.

Another factor confirming the exceptional nature of the presented possibility of revision of ECtHR judgments may be found in previous practice. No successful requests for revision reached the ECtHR until 1996. In academic writings on the subject this was found not to be astonishing as:

"cases in which, after the final judgment, an originally unknown fact of decisive importance is discovered are very rare. It is even less likely that

5 This factor was very visible in the first revision judgments in which two separate decisions were delivered, i.e., the first on admissibility and the second on the merits of the case; see the Case of Pardo v. France (revision-admissibility), Application No. 13416/87, judgment of 10.7.1996; and Case of Gustafsson v. Sweden (revisionadmissibility), Application No. 18/1995/524/610, decision of the Screening Panel of 13.10.1997.

6 Case of Pardo v. France, supra note 5, at para 11.

7 Ibidem, at para 21. 
such situation will occur after lengthy local proceedings and the elaborate proceedings before the Commission and the Court"

The present picture looks otherwise. Thus, until the end of March 2012, the Strasbourg statistics indicate that there have been only 51 revision judgments (amongst which 12 cases are against Italy; 9 against Poland; 9 against Turkey; 8 cases against Romania; 5 against France; 2 cases each against Hungary and Sweden; and 1 case each against Germany, the United Kingdom, Greece, and Austria) ${ }^{9}$.

The main aim of the present article is to systematize the problems which appeared against the background of the aforementioned judgments. Additionally, it aims to posit an answer to the question concerning the guaranteed possibility for revision of a judgment, both in an individual and a general dimensions.

An analysis of revision judgments case-law will be undertaken both in general and more specific ways. However, before going into details, it should be remembered that individuals received "full" procedural status before the ECtHR only in 1994, i.e., following the entry into force of Protocol No. 9 to the ECHR ${ }^{10}$. This factor had logical implications as regards the possibility for an individual to gain direct access to the legal instruments covered by the Rules of the ECtHR.

A general analysis of the ECtHR revision judgments leads to the following conclusions: Firstly, up until the date on which this article was written, the main procedural value of the possibility to request revision of a judgment was connected primarily with the situation of the State-Party concerned, since it represented the relevant legal instrument allowing the State to accommodate its law to the new background of the judgment which appeared during the time of the Strasbourg trial. Such situations

8 P. van Dijk, G.J.H. van Hoof, Theory and Practice of the European Convention on Human Rights, Deventer-Boston 1990, at p. 187.

9 Statistics available at www.coe.int in the HUDOC database of the ECtHR. More detailed calculations were undertaken directly by the Author.

10 Protocol No. 9 to the Convention for the protection of Human Rights and Fundamental Freedoms, Rome 6.11.1990, 'European Treaty Series', No. 140. In fact, the evolution of the individual's position in the Strasbourg procedure began a little earlier, i.e., under the Rules of the Court of 1.1.1983 - see: L.E. Pettitti, E. Decaux, P.H. Imbert, P.H. Teitgen, op. cit., at p. 799. 
mainly concerned cases in which the direct victim of a violation of the ECHR died prior to delivery of the judgment and the legal consequences of such death insofar as concerning the State's obligations to properly execute the judgment. The cases included in this group can differ according to the moment of death of direct victims and the attitudes of the heirs, their legal entitlements and the final number of those entitled.

Secondly, the relatively small number of revision judgments in existence confirms the assumption that this procedure finds application only in "exceptional" situations. However, this same fact may either confirm the high quality of ECtHR adjudication or conversely may indicate the "stubborn" attitude of the European judges as concerns their good will to modify their earlier conclusions.

Thirdly, within the whole group of revision judgment cases there are few which are connected with true satisfaction of the party concerned. It seems proper to conclude that even the few cases resulting in a visible "success" for the interested party cannot be neglected, since they constitute conclusive evidence of the potential impact of the discussed legal solution.

As an illustration of the exceptional nature of the revision procedure, the two first revision judgments should be recalled. Thus in Pardo v. France case the European Commission of Human Rights submitted a revision request to the ECtHR. Of course, the Commission was motivated by the applicant who sent a letter containing detailed information. The applicant claimed to be the victim of a violation of Article 6(1) ECHR. In his opinion, the procedure in his case failed to meet the requirement of fairness since he was unable to produce all necessary pieces of evidence. In its original judgment, the ECtHR ${ }^{11}$ - despite the contrary position of the Commission - found that the respondent State had not violated the said provision. However, following the judgment, the applicant received two new documents against the background of which - in his opinion information submitted by the Government in the main proceedings was untrue. Accordingly, the new documents were capable of having a decisive influence on the ECtHR's findings. The Commission's revision request in this case was declared admissible (by five votes to four) ${ }^{12}$. Nonetheless,

11 Case of Pardo v. France, supra note 5.

12 The dissenting four judges noted that „revision is an exceptional procedure and the admissibility of any request for revision of a judgment of the Court under this procedure must be subject to strict scrutiny". 
upon a strict analysis of the two documents, the ECtHR unanimously dismissed the request for revision and concluded that the documents would not have had a decisive influence on the original judgment. Accordingly, there were no real grounds for revision and the request was unfounded ${ }^{13}$.

Similarly, in the Gustafsson v. Sweden case, concerning the collective bargaining system, the ECtHR's original judgment concluded (by twelve votes to seven), that Article 11 ECHR had not been violated ${ }^{14}$. Once again, the findings of the ECtHR differed from those of the Commission which, by majority opinion, found a violation of Article 11 to have taken place. The applicant successfully submitted a request for revision of the original judgment. However, during the proceedings on the merits of the case, the ECtHR concluded that the disputed facts were merely ancillary to the reasons given in support of the original judgment's conclusion. In this context, the new evidence adduced by the applicant would not have had a decisive influence on the finding as regards the Article 11 complaint. Accordingly, "the evidence did not offer any ground for revision" (by 16 votes to 1$)^{15}$. It is noteworthy that the dissenting judge in this case criticized the majority's adoption of an overly formalistic and legalistic approach to the applicant's request as regards "a very restricted interpretation of what can be considered 'decisive"16.

As regards subsequent ECtHR revision judgments, the situation did not essentially differ in such a sense that, despite a positive decision concerning the admissibility of a particular request, the Court's final judgment disagreed with the conclusions offered by the requesting party. Most frequently, the Court made reference to the "non-decisive influence" of the newly discovered facts. However, this criterion played a less crucial role in later cases and was invoked relatively rarely ${ }^{17}$.

13 Case of Pardo v. France (revision-merits), Application No. 13416/87, judgment of 29.4.1997, at paras 22-23.

14 Case of Gustafsson v. Sweden, Application No. 18/1995/524/610, judgment of 25.4.1996.

15 Case of Gustafsson v. Sweden (revision), supra note 5, at para 32.

16 See dissenting opinion of Judge M. Bonnici, ibidem, at para 2.

17 See e.g., Case of S.C. Concordia International S.R.L. Constanta v. Romania, Application No. 38969/02, judgment (revision) of 20.12.2011 ("It should be noted that some of the judgments are available only in French. For this reason the present article uses two languages references to the Strasbourg case-law"). 
It also seems appropriate to make reference to the difficult and controversial Zwierzyński v. Poland case ${ }^{18}$. The Polish Government strenuously attempted to modify the original judgment, which found Poland to have violated Article 1 of Protocol No. 1 ECHR and Article 6(1) ECHR. In relation to the breach of Article 6 ECHR, the respondent State was ordered to pay 15000 PLN as non-pecuniary damages and 25000 PLN as costs and expenses. Since the Court was unable at the time to rule on the application of Article 41 to the violation of Article 1 of Protocol No 1, the ECtHR delivered its judgment separately and ordered Poland to pay the applicant a total of Euro 160,500 in respect of material damage and Euro 16,500 as moral damages and a further Euro 3,090 as costs and expenses. The details of the case were complicated and concerned the acquisition of title to property through adverse possessions. Likewise, the procedural aspects of this case were particularly complicated as the Government attempted to question the applicant's status as a victim. These efforts were exceptionally strong (Poland attempted to have the case referred to the Grand Chamber and then made three requests for revision of the judgment, pursuant to the Rules of the ECtHR ${ }^{19}$. Finally, in an unanimous opinion, the ECtHR rejected the request for revision on the basis that no new facts had arisen, as required by Rule 80 of the Rules of the ECtHR.

The third revision case to be considered contained a new element, i.e., a dilemma as to whether or not the new facts "could reasonably have been known" to the applicants prior to delivery of the original verdict ${ }^{20}$. The case concerned the interests of two applicants who participated in nuclear tests conducted by the United Kingdom on Christmas Island in the Pacific Ocean in 1958. Given the applicants' inability to access the

18 Case of Zwierzyński v. Poland, Application No. 34049/96, judgment (revision) of 6.3.2007.

19 It should be noted that a request for revision does not influence the term concerning a request to refer the case to the Grand Chamber; see L. Garlicki (ed.), 'Konwencja o Ochronie Praw Człowieka i Podstawowych Wolności, Tom II. Komentarz do artykułów 19-59 oraz do Protokołów dodatkowych' [Convention for the Protection of Human Rights and Fundamental Freedoms, Vol. II. Commentary to Articles 19-59 and Additional Protocols], Warszawa 2011, at p. 331.

20 Case of McGinley and Egan v. the United Kingdom (Revision), Application No. 21825/93 and 23414/94, judgment of 28.1.2000. 
relevant documentation, they claimed to be the victims of Article 6 ECHR insofar as concerned their application for service disability pensions. The Commission's opinion in this particular case unanimously concluded that there had been a violation of the said provision. Nevertheless, the ECtHR's original judgment concluded (by six votes to three) that there had been no violation of Article 6(1) ECHR ${ }^{21}$.

The details of this revision case, referred by the Commission to the ECtHR, once again remind us that this procedure was meant to be exceptional in nature and ought to have been subjected to strict scrutiny. In the judges' opinion, the applicants possessed sufficiently detailed knowledge of important developments which took place at the relevant time from information and copy letter in their possession. Thus, although copies of the correspondence were obtained by the applicants following delivery of the original judgment, both of the applicants were aware of the existence of such correspondence. Accordingly, the applicants could have reasonably known the facts at stake prior to delivery of the original judgment. Consequently, their revision request was rightly rejected (by five votes to two $)^{22}$.

This case contains a very interesting element connected with the new wording of Rule 80, which was underlined by those judges supporting the minority opinion. Both such judges noticed that the ECtHR dismissed the Commission's request for revision "on the basis not of a knowledge of the facts by the latter but of the idea that the applicants could reasonably have known them - a quite different matter"23.

A similar dilemma arose in the Bugajny and others v. Poland $\operatorname{case}^{24}$, in which the ECtHR's original judgment held there to have been a violation of Article 1 of Protocol No. 1 ECHR and consequently awarded the applicants jointly the sum of Euro 247,000 as pecuniary damages and Euro 18,725 under the heading of procedural costs. The Government requested

21 Case of McGinley and Egan v. the United Kingdom, Application No. 21825/93 and 23414/94, judgment of 9.6.1998.

22 Case of McGinley and Egan v. the United Kingdom (Revision), supra note 20, at paras 35-36.

23 See dissenting opinion of Judge J. Casadevall joined by Judge R. Maruste, Ibidem, at para 2(b).

24 Case of Bugajny and others v. Poland (Revision), Application No. 22531/05, judgment of 15.12.2009. 
revision of the original judgment, dated 6.11.2007, since it disagreed with the Court's conclusion concerning the violation of Article 1 of Protocol No. 1 ECHR. The main argument relied upon by the Government was that there had been no interference with the applicants' possessions, since they remained the lawful owners of the land in question and were fully entitled to continue utilizing that land.

When considering this new information the Court noted that, when the judgment was handed down, the applicants' conduct was improper as they had not informed the Court of the existence of contracts between their companies and the owners of the plots of land. Nonetheless, this did not alter the fact that the Government did not refer to any information concerning the legal status of the relevant properties, details of which were duly recorded in the land registers. Moreover, the Government did not even attempt to consult the relevant registers. For these reasons, the ECtHR (by five votes to two) rejected the Government's request for revision, since the entries in the land register which were regarded by the Government as relevant to the finding of a violation of the Convention standard represented facts "which could not have reasonable been known to the party" as required by Rule $80(1)^{25}$.

Finally, in the Mosoiu and Pasarin v. Romania case ${ }^{26}$ the ECtHR's original judgment concluded that there had been a violation of Article 1 of Protocol 1 ECHR and consequently ordered that the victims be paid a sum of Euro 98,424 in respect of material damage. However, following the judgment, the legal situation of the co-owners altered in such a way that the first applicant received part of the property and transferred certain of her rights to the second applicant. Given this new factual and legal context, the Government requested revision of the original judgment. The ECtHR unanimously concluded ${ }^{27}$ that the original application was inadmissible. As regards the second applicant, the Court confirmed the existence of a violation of Article 1 of Protocol No. 1 and ordered the State to make restitution of the property or, alternatively, to pay the sum of Euro 98,424 in respect of material damage.

25 Ibidem, at paras 25-26.

26 Case of Mosoiu and Pasarin v. Romania, Application No. 10245/02, judgment of 7.2.2008.

27 Case of Mosoiu and Pasarin v. Romania (Revision), Application No. 10245/02, judgment (revision) of 28.6.2011. 
Chronologically, the next case on the list may be said to have begun the trend of using the possibility for revision of a ECtHR judgment in a new legal situation arising in consequence of the death of the direct victim prior to delivery of the original judgment. Certainly, such a situation is capable of exerting a strong influence on final execution of the relevant judgment. A comparable situation occurs following the liquidation of an applicant company ${ }^{28}$.

Thus, in the Gucci v. Italy case ${ }^{29}$, at the request of the applicant's lawyer, who informed the Court of the death of his client and the existence of his two legal heirs, the ECtHR's revised judgment equally divided the sum of just satisfaction awarded to the applicant (Euro 32,000) between the heirs. A similar situation may be found in a series of subsequent cases, with minor differences concerning the subject who submitted the revision request, i.e., the applicant's advocate ${ }^{30}$ or the government of the respondent State $^{31}$ and even both parties simultaneously ${ }^{32}$. Another differential concerned the number of heirs - thus, where only one heir existed, the revised judgment merely modified the personal data contained in the original judgment ${ }^{33}$.

28 See case of Horváth and others v. Hungary (Revision), Application No. 45407/05, judgment of 17.5.2011; case of SC Placebo Consult SRL v. Romania (Revision), Application No. 28529/04, judgment of 21.6.2011.

29 Case of Gucci v. Italy, Application No. 52975/99, judgement of 1.10.2002.

30 This represents the prevailing situation; see e.g., Case of Simone and Pontillo v. Italy (Revision), Application No. 52831/99, judgment of 3.10.2002; Case of Scaccianemici v. Italy (Revision), Application No. 51090/99, judgment of 3.10.2002; Case of Viola v. Italy (Revision), Application No. 44416/98, judgment of 7.11.2002; Case of Carolla v. Italy (Revision), Application No. 51127/99, judgment of 28.11.2002; Case of Guerra and Fusco v. Italy (Revision), Application No. 40601/98, judgment of 31.7.2003; Case of Lutz v. France (Revision), Application No. 49531/99, judgment of 25.11.2003.

31 See Case of Santoni v. France (Revision), Application No. 49580/99, judgment of 1.6.2004; Case of Perhirin and 29 others v. France (Revision), Application No. 44081/98, judgment of 8.4.2003; Case of Armando Grasso v. Italy (Revision), Application No. 48411/99, judgment of 29.4.2003.

32 Case of Kulikowski v. Poland (Revision), Application No. 18353/03, judgment of 21.12.2010.

33 See e.g., Case of Ragas v. Italy (Revision), Application No. 44524/98, judgment of 17.12.2002; Case of D’Ammassa et Frezza v. Italy (Revision), Application No. 44513/98, judgment of 9.1.2003. 
Finally, in the above-presented context an interesting trend is identifiable in the attitude of the ECtHR, depending on the behaviour of the applicant's heirs, i.e., their own participation in the Strasbourg procedure. In the Gabay v. Turkey ${ }^{34}$ and Bolovan v. Romania cases ${ }^{35}$, the applicants had died prior to adoption of the judgments. In the Governments' opinion, it was unable to execute the later judgment, especially given the nonparticipation of the heirs in the original procedure. The ECtHR stated that, since no relatives of the victims had expressed the wish to pursue the application, it was "no longer justified to continue the examination of the case" and by six votes to one in the first case, and by unanimous decision in the second case, the judgments were revised in toto and the cases were struck off the list.

This situation appears controversial, since in many other cases the ECtHR ordered the sum accorded as just satisfaction to be paid to the surviving heirs. Thus, in the opinion of Judge G. Bonello, a visible change in the ECtHR's position presented in the Gabay v. Turkey case led to the applicant's family being denied "what had been routinely allowed in every other similar case, whether the Court had been informed of the applicant's death by the applicant's family, or by the Government" 36 .

In fact, such context appeared in the Resul Sadak and others v. Turkey case $^{37}$, where one of twelve applicants died prior to adoption of the judgment. A request for revision of the original judgment was submitted both by the Government and the applicants' representative. According to the Government, the heirs' application should have been struck off since they had not expressed their wish to pursue the application whilst it remained pending before the Court. Nonetheless, the ECtHR revised the judgment and awarded the heirs jointly the amount of Euro 1,800 in respect of non-pecuniary damages and the appropriate amount in respect of costs and expenses.

34 Case of Gabay v. Turkey (Revision), Application No. 70829/01, judgment of 27.6.2006.

35 Case of Bolovan v. Romania (Revision), Application No. 64541/01, judgment of 20.9.2011.

36 See dissenting opinion of Judge G. Bonello in the case of Gabay v. Turkey, supra note 34 , at para 5 .

37 Case of Resul Sadak and others v. Turkey (Revision), Application No. 74318/01, judgment of 8.1.2009. 
Naturally, the aforementioned problem does not arise where the applicant's death was preceded by the active participation of the heirs who subsequently seek to pursue the proceedings before the ECtHR ${ }^{38}$. In such cases, the ECtHR's position has been consistently positive towards the deceased applicant's heirs.

Against the background of the series of cases discussed above, it would be proper to conclude that the possibility to revise an original judgment, provided for by the Rules of the ECtHR, has become an important measure to ensure the proper and effective execution of judgment in a situation where a new factual context has arisen. Despite the rather formal nature of such an application, the revision procedure cannot be neglected since the proper execution of ECtHR judgments lies at the very "heart" of the European justice system.

It is important to stress that, when dealing with a request for revision of a judgment, the ECtHR has paid strict attention to all formal requirements, such as the decisive and truly new nature of the discovered facts and the prescribed time limits. For example, the latter factor formed the basis of the rejection of the applicant's request for revision in Andrea Corsi v. Italy case $\mathrm{c}^{39}$.

Such detailed scrutiny of the Government's request was undertaken in Stoicescu v. Romania case $\mathrm{c}^{40}$, albeit it ultimately led the ECtHR to rule unanimously in favour of the request. In this case, the original judgment of 4.6.2003 found that a violation of Article 6(1) ECHR, read in conjunction with Article 1 of the Protocol No. 1 ECHR, had taken place. Given the existence of newly obtained facts, the ECtHR declared the application of $\mathrm{M}$. Stoicescu incompatible ratione personae and consequently revised the original judgment in toto. Certainly, whilst such situations may be regarded as confusing, they nevertheless confirm the correctional nature of the revision procedure.

38 Case of Wypukoł-Piętka v. Poland (Revision), Application No. 3441/02, judgment of 8.6.2010; case of Klimkiewicz v. Poland (Revision), Application No. 44537/05, judgment of 21.12.2010; case of Dyller v. Poland (Revision), Application No. 39842/05, judgment of 15.2.2011.

39 Case of Andrea Corsi v. Italy (Revision), Application No. 4221098, judgment of 2.10.2003, at para 10 .

40 Case of Stoicescu v. Romania (Revision), Application No. 31551/96, judgment of 21.9.2004. 
A similar situation appeared in the Nicola v. Turkey case ${ }^{41}$, in which continuing violations of Article 8 ECHR and Article 1 of Protocol No 1 were found. In its original judgment, the ECtHR held that the applicant's son enjoyed legal standing to continue the proceedings. The Court's finding of the above-mentioned violations was based on the assumption that the applicant had been the owner of a particular house. This assumption transpired to be incorrect. As this fact was unknown to the ECtHR or the Government, the request for revision was declared admissible and the Strasbourg judges unanimously decided to revise the original judgment, which had been incompatible ratione personae with the provisions of the Convention.

In the Bauman v. Austria case ${ }^{42}$ the ECtHR was confronted with the problem of interpreting Rules 80 and 81 (relating to clerical errors). Against the background of the submissions of the Government, which attempted to qualify the applicant's request as out of time within the meaning of Rule $81 \mathrm{ECtHR}$, the Court disagreed that mistakes contained in the original judgment and concerning costs and expenses were of a purely clerical nature. According to the ECtHR, the Government's submissions had a decisive influence on the original judgment. Accordingly, the Court decided to revise the judgment as regards the conclusions concerning costs and expenses. Thus, whereas the original judgment awarded the sum of Euro 5,906.91 as costs and expenses, the revised calculations amended this to Euro 4,242.91.

Amongst the revision judgments there is a very interesting group of cases concerning the problem of correctly applying the concept of just satisfaction (previously Article 50, currently Article 41 ECHR). Once again, such an application may be made by any of the parties to the case. It should be remembered that, in the early Strasbourg jurisprudence, such a situation was not so simple, as demonstrated by the Ringeisen v. Austria case $^{43}$ in which, when invoking Article 50 ECHR following delivery of the original judgment, the respondent Government relied upon Article 52

41 Case of Nicola v. Turkey (Revision), Application No. 18404/91, judgment of 26.10.2010.

42 Case of Bauman v. Austria (Revision), Application No. 76809/01, judgment of 9.6.2005.

43 See supra note 1. 
ECHR, i.e., the finality of the original verdict. Nonetheless, according to the ECtHR:

"it would be a formalistic attitude alien to international law, to maintain that the Court may not apply Article 50 save on condition that it either rules on the matter by the same judgment which found a violation or that this judgment has expressly kept the case open"44.

Whereas the previous situation may be regarded as uncontroversial, this may not be said of cases in which the applicants failed to comply with procedural obligations connected with the application of Article 41 of the Convention. Thus, in the Andrea Corsi v. Italy case ${ }^{45}$, in which the applicant failed to submit to the Court the necessary specific claim concerning just satisfaction, no order concerning just satisfaction was contained in the original judgment. The applicant subsequently attempted to persuade the Court that the claim was in fact sent by her legal representative but had failed to arrive at the Court. In this situation, the ECtHR unanimously rejected the request for revision of the original judgment and supported its position with Rules 38 and 60 ECtHR.

Interestingly enough an analysis of revision judgments leads to the conclusion that, even in such a problematic context, the individual applicant need not necessarily lose the case. Indeed cases exist in which, despite procedural failings, the application was considered successfully for the applicant requesting the revision. Thus, in the Epple v. Germany case ${ }^{46}$ an applicant who had been found to be the victim of a violation of Article 5(1)(b) ECHR had failed to submit necessary information concerning the application of Article 41 of the Convention. The applicant explained that he had never been invited to do so. In a unanimous opinion, the ECtHR ordered that the State pay to the applicant a sum of Euro 1,700 in respect of costs and expenses and at the same time decided that the finding of a violation in itself constituted just satisfaction as far as moral damages were concerned.

44 Ibidem, at para 18.

45 Supra note 39.

46 Case of Epple v. Germany (Revision), Application No. 77909/01, judgment of 15.12.2005. 
Similarly, in the Sabri Tas $v$. Turkey case ${ }^{47}$ the applicant's lawyer requested a revision of the judgment given the absence of just satisfaction under Article 41 ECHR. In the original judgment, the Court found a violation of Article 6(1) and Article 5(3) ECHR. The main argument invoked by the lawyer was that the applicant had never been requested to submit a just satisfaction claim. The ECtHR accepted this reasoning and, in a unanimous decision, revised the original judgment by ordering that the applicant be paid the sum of Euro 8,000 in respect of non-pecuniary damage and Euro 2,500 in respect of costs and expenses.

The Karagiannis and others $v$. Greece case ${ }^{48}$ concerned an alleged violation of Article 1 of Protocol No. 1, read in conjunction with Article 6(1) ECHR. The ECtHR, when delivering its judgment on the merits of the case, was unable to rule on the issue of just satisfaction, so the question was left unanswered. In the meantime, the respondent Government informed the Court of the death of three of the applicants and, since no information existed concerning the heirs, requested that the interests of the deceased victims be excluded from the just satisfaction reward. In a unanimous decision the ECtHR revised the original judgment and excluded those deceased applicants.

A somewhat similar situation concerns the problem of applying just satisfaction to cases in which, following the applicant's death and preceding delivery of the judgment, problems existed as regards identification of the proper heirs. The requests of Governments concerning the in toto revision of such judgments - depending on the circumstances - can only lead to modification of such part of the judgment as concerns just satisfaction. According to the ECtHR, the original decision on the merits of the case (Article 5(1)(e) and Article 4 of the Convention) remained valid but, nevertheless, it conclude that it was impossible to make an order on just satisfaction $^{49}$.

47 Case of Sabri Tas v. Turkey (Revision), Application No. 21179/02, judgment of 25.4.2006.

48 Case of Karagiannis and others v. Greece (Revision), Application No. 51354/99, judgment of 8.7.2004.

49 See Case of C.B. v. Romania (Revision), Application No. 21207/03, judgment of 19.7.2011. 
Still another context appeared in the Adamczuk v. Poland case ${ }^{50}$ concerning the violation of Article 6(1) ECHR due to the length of legal proceedings. According to the Government's request, this judgment should have been revised in relation to just satisfaction (the applicant was awarded Euro 14,400 for non-pecuniary damage) since the Government had never received the applicant's pleadings on this issue and was consequently unable to comment thereupon. The Government argued that the applicant's claims should have been rejected as they were unsupported by any evidence of the physical or mental harm allegedly suffered. Dealing with this argument, the ECtHR considered that the unreasonably lengthy procedure must have produced such negative effects as stress and frustration, which would not be sufficiently compensated merely by a declaratory judgment. Accordingly, the original amount of just satisfaction in respect of non-pecuniary damage was justified and upheld in the revised judgment.

The revision procedure may also be utilized in respect of decisions on costs and expenses. In the Fonyódi v. Hungary case, the ECtHR's original judgment ${ }^{51}$ found a violation of Article 6(1) ECHR (length of civil proceedings) and awarded the applicant Euro 14,400 for non-pecuniary damage. Simultaneously, the Court rejected the applicant's claim for costs and expenses as unsubstantiated. The applicant replied that an invoice concerning legal fees had been properly submitted to the Court within the appropriate time limits. The ECtHR confirmed this argument and explained that it had simply been overlooked. Thus, whilst revising the original judgment, the ECtHR unanimously decided that the respondent State was required to pay the applicant Euro 1,000 in respect of costs and expenses ${ }^{52}$.

This case offers a good illustration of the kind of flexible policy that can be practiced in Strasbourg. Certainly, the present conclusion goes much further than that of the early Brogan v. the United Kingdom case $^{53}$, in which the ECtHR held that, given the applicant's failure to

50 Case of Adamczuk v. Poland (Revision), Application No. 30523/07, judgment of 15.6.2010.

51 Case of Fonyódi v. Hungary, Application No. 30799/04, judgment of 7.10.2008.

52 Case of Fonyódi v. Hungary (Revision), Application No. 30799/04, judgment of 7.4.2009, at paras 8-9.

53 Case of Brogan and others v. the United Kingdom (Article 50), Application No. 11209/84; 11234/84; 11266/84; 11389/85, judgment of 30.5.1989. 
request examination of the problem of reimbursing costs and expenses incurred, the decision became final. The ECtHR "cannot entertain the applicants' subsequent claim in this respect, on whatever basis it may be put forward"54.

Perhaps it remains a little too soon to formulate definitive conclusions on the application of the revision procedure. However, certain regular features seem to be sufficiently clear as to enable and justify their proper appraisal. One such feature is connected with the growing tendency of successful "revisions" which began to appear in the Strasbourg statistics only from the mid-1990's. Could this be connected with a new vision of the whole control procedure elaborated in Protocol No. 11 to the Convention? Does the possibility of so-called "inner-appeal" change the strong presumption concerning the finality of ECtHR judgments? Is this fact connected in any way with the growing problem of improper execution of judgments at the domestic level? In this last regard, the answer could simply be positive, for the personal details changed by the ECtHR in many judgments certainly made it possible for the Governments concerned to execute the Strasbourg verdict. As regards other questions, certain of them still remain in the sphere of more or less substantiated intellectual speculations.

Whatever the reason, one thing seems to remain beyond doubt. The proper execution of final verdicts is a precondition for true and effective justice. Likewise, even the small numbers of cases in which individual successes have been witnessed, mainly dealing with the financial aspects of a judgment, ensure that steps continue to be made in the same positive direction.

However, besides this relatively optimistic conclusion, one remaining problem seems to be seriously controversial, namely the long periods that transpire between the moment of death of a direct victim, the date of the ECtHR judgment and the passing of information to Strasbourg to support request to revise the original decision following changes in the substantive context of the case. In some cases, such a period has lasted for years - as was true of the Veli Yalcin v. Turkey $\operatorname{case}^{55}$, in which the applicant

54 Ibidem, at para 7.

55 Case of Veli Yalcin v. Turkey (Revision), Application No. 29459/05, judgment of 19.4.2011. 
died in 2008, the ECtHR delivered its judgment in 2010, and in 2010 received information about the applicant's death from his advocate and a request to revise the original judgment. Earlier, an analogous situation appeared in the Gattone and others v. Italy case ${ }^{56}$ - the applicant died in 2000, the original judgment of the ECtHR was delivered in 2002 and the applicant's advocate informed the Court about his client's death in 2002 whilst requesting revision of the previous judgment.

Besides being surprising, the presented situations do not create the best image of proper co-operation between an applicant, his/her lawyer and respondent governments. It should be relatively uncontroversial to posit the conclusion that, if such co-operation took a stricter and more formal nature, most revision requests would be simply unnecessary and that the subsidiarity principle of the Strasbourg procedure would be better protected. Conversely, it would also be justified to enquire about the reason why such situations were absent in the early practice of the ECtHR. Does this mean that the lower numbers of cases dealt with in Strasbourg resulted in better inter-communication? The Author of this article would be grateful for any further suggestions.

56 Case of Gattone and others v. Italy (Revision), Application No. 51103/99, judgment of 3.10.2002. 